\title{
Twelve years of vegetation change in an artificial marsh after the transfer of plants and hydrological restoration
}

\author{
Takashi Nishimoto • Yoshio Hada
}

Received: 15 May 2011/Revised: 29 November 2011/Accepted: 2 December 2011/Published online: 21 December 2011

(C) The Author(s) 2011. This article is published with open access at Springerlink.com

\begin{abstract}
For 12 years starting from 1991, we performed vegetation surveys every $2-3$ years at permanent plots located in an artificial marsh which was constructed in former rice paddies through sod transplantation from a natural marsh. Management of the artificial marsh was conducted to maintain the condition of the donor vegetation by removing unnecessary plants and ensuring a water supply of constant quality and quantity. However, the structure and floristic composition of the donor vegetation were destroyed during sod transplantation, and eutrophic water was supplied before the construction of a well in year 5. The transition of communities identified in the artificial marsh was monitored periodically at 34 fixed plots established three years after transplantation, with a further two plots added in year 7. Seasonal changes in surface water chemistry were also monitored. While the main communities of the artificial marsh resembled that of the donor marsh, two other communities were also identified at arid or muddy sites, where dominant plants had grown from seeds or propagules. After 12 years, we identified three communities (with one community containing two subunits), the dominance of which changed among the plots over the years. The communities developed along two main gradients, dry to wet and secondary succession. The first gradient was
\end{abstract}

T. Nishimoto $(\bowtie)$

Okayama Prefectural Nature Conservation Center,

730 Taga, Wake-cho, Wake-gun, Okayama 709-0524, Japan

e-mail: fvbs5491@mb.infoweb.ne.jp

\section{Y. Hada}

Department of Biosphere-Geosphere System Science, Faculty of Information, Okayama University of Science, 1-1-1 Ridai-cho, Kita-ku, Okayama 700-0005, Japan e-mail: y_hada@big.ous.ac.jp characterized by species groups favoring dry conditions, while the second gradient was characterized by species groups favoring disturbed conditions. The original composition recorded for donor marsh plants was not established by year 12 after transplantation to the artificial marsh.

Keywords DCA - Ecological gradient - Hydrology · Plant community $\cdot$ Sod transplantation · Floristic composition

\section{Introduction}

In recent decades, extensive creation and restoration work has been carried out on American and European wetlands (e.g., Middleton 1999; Pfadenhauer and Grootjans 1999; Mitsch 2007). Improving currently utilized strategies for wetland restoration and conservation requires a broad understanding of hydrological mechanisms that are associated with habitat fragmentation in the plant communities of wetlands (van Loon et al. 2009). Efforts to conserve wetlands in Japan were initiated in the 1990s, with the aim to restore or create new biotopes (Hada 1993, 1997; Hada et al. 1995; Iwase 2001; Yabe et al. 2002). However, the outcomes of these efforts are difficult to gauge, because observational timescales have been too short and because there has been a lack of management planning for restoration.

Many studies have demonstrated the difficulties involved in conserving wetlands, and it is now widely accepted that if small remnant wetlands situated in highly modified landscapes are to be preserved, human intervention is essential (Lloyd et al. 1993). Furthermore, conservation management of wetland ecosystems should operate at a regional scale (Barendregt et al. 1995). Wetlands have always been of particular significance for mankind (Pfadenhauer and 
Grootjans 1999). To preserve the biotic assemblages of wetlands, it is sometimes necessary to transplant communities from a donor wetland that faces destruction (Middleton 1999). However, many restoration projects often face difficulties. Kentula et al. (1992) suggested that failure was generally associated with improper hydrological conditions in new wetlands. In a review of vegetation rehabilitation projects in Japan, Tsuji (2001) also concluded that, despite extensive efforts to restore original ecosystems, many projects have failed due to a dearth of knowledge on wetland creation and restoration. Choi (2004) investigated different practices of wetland restoration and concluded that large components of restoration projects were probably unsuccessful for the following reasons: unrealistic goals; inadequate restoration plans; lack of explicit and quantitative evaluation criteria; lack of ecological understanding; social, economic, and political constraints; or a combination of these factors. As a result, there are a limited number of viable cases available against which we can evaluate the success of our marsh restoration program.

Numerous studies have investigated relationships between vegetation and hydrological systems in wetlands facing destruction through drainage and alteration in water chemistry (Barendregt et al. 1995; Wassen and Grootjans 1996; Mitsch et al. 1998; Pfadenhauer and Grootjans 1999; Schot et al. 2003; McCartney and Hera 2004; Tzialla et al. 2006; Malson et al. 2006; van Diggelen et al. 2006). Different communities and species may be represented along wet-dry and nutrient poor-rich gradients in a marsh, suggesting that water level and water composition are important abiotic factors for marsh development, as previously reported (Gorham 1956; Moore and Bellamy 1974; Waughman 1980; Gore 1983; Bootsman and Wassen 1996; Lamers et al. 2002). In a study of a Japanese wetland, Tsuyuzaki et al. (2004) observed that vegetation patterns were related to large-scale moisture conditions and small-scale light and soil conditions. Nishimura et al. (2009) demonstrated that ground water level is more important for revegetation after transplantation than nutrient status. One of the most important factors in changes in the floristic composition of wetland vegetation is a change in the physical or chemical conditions of the habitat (e.g., a change in water or nutrient level) that favors the growth of some species over others (van der Valk 1981).

However, joint studies of hydrological dynamics and vegetation responses remain relatively rare, resulting in a rather limited information base for rational restoration strategies (Large et al. 2007). Ecosystem creation and restoration (sometimes referred to as "ecological engineering") comprise a relatively new discipline that, although well developed in terms of practical procedures, requires a sounder foundation in ecological theory to support many of the empirical findings (Mitsch et al. 1998). There is a large global decline in wetland biodiversity due to drainage, eutrophication, acidification, and fragmentation (Mitsch and Gosselink 1993). Complete restoration may be impossible because of irreversible changes in the physical and chemical characteristics of soil (Wassen and Grootjans 1996). Many restoration projects on degraded wetland ecosystems have attempted to restore biodiversity; however, in many cases, it is not clear whether failure is attributable to abiotic or biotic factors (Pfadenhauer and Klotzli 1996). Nishimura et al. (2009) demonstrated that original vegetation had not returned three decades after peat mining. They suggested that a necessary first step in developing a restoration strategy is the examination of natural revegetation patterns in relation to environmental variables. Mitsch and Wilson (1996) pointed out that the creation and restoration of new wetlands to compensate for wetland habitat loss is a newly developing science/technology, the success of which still needs to be defined and measured. They further recommended that mitigation projects on freshwater marshes require a minimum of 15-20 years (rather than five years) of observation before the success of an enterprise can be ascertained. As noted by Atkinson et al. (2005), many studies have chronicled the early development of vegetation in wetland restoration projects, but very few have followed the changes in floristic composition for more than ten years.

Matthews and Endress (2007) demonstrated that better goals for wetland restoration may be developed by basing performance standards on earlier achievements of similar restoration projects, through identifying consistent temporal trends in the attributes of restored sites, and by using natural wetlands as reference environments. Because there are very few examples of successful wetland restoration, there is little suitable information on the skills and methods required to create an artificial marsh. The knowledge deficit is especially apparent in the selection of appropriate groundwater levels and in procedures for the effective transplantation of donor plants to new sites. Our research group successfully transplanted vegetation from a donor marsh to an artificial marsh, and then tracked the transition of plant communities over a 12-year period, while managing water chemistry and removing unsuitable plants on an annual basis (Hada et al. 1995; Nishimoto 2001; Nishimoto and Hada 2002). Here, we report (a) the trajectories of floristic composition from data collected in permanent plots 3-12 years after the establishment of the artificial marsh, and (b) the relationship between changes in communities and water parameters. Based on these results, we also discuss the management actions that are required during the first stage of artificial marsh restoration. 


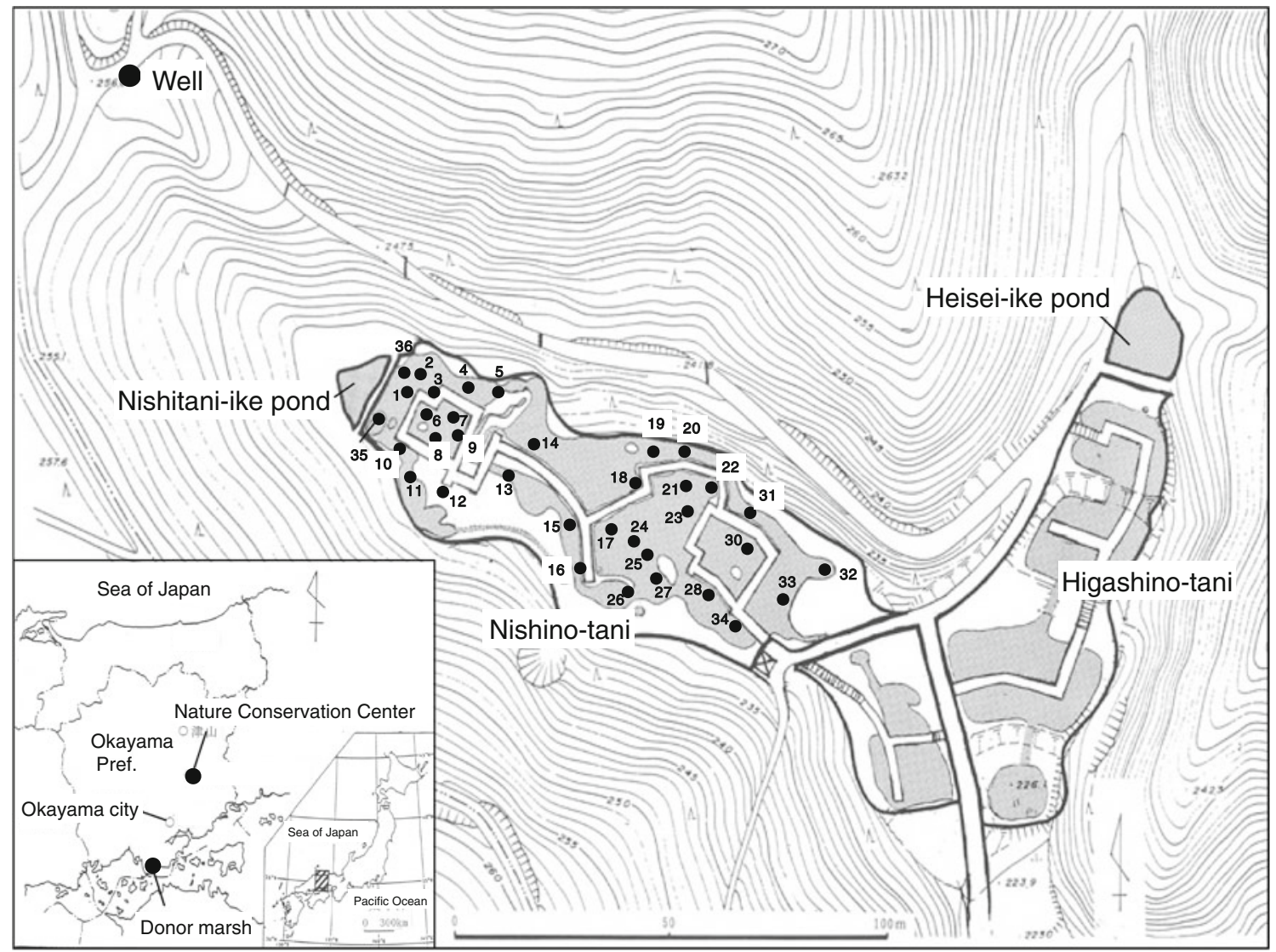

Fig. 1 Landform of the artificial marsh, positions of permanent plots (filled circles, 1-36), and geographical locations of the donor marsh and the artificial marsh in the Okayama Prefectural Nature

\section{Materials and methods}

Study sites

The Marsh Land Garden was created from former rice paddies in the Okayama Prefectural Nature Conservation Center, which is located in central Okayama prefecture in western Japan $\left(34^{\circ} 51^{\prime} \mathrm{N}, 134^{\circ} 03^{\prime} \mathrm{E}\right.$; Fig. 1). The Marsh Land Garden has two drainage sectors: the western part with a narrow drainage area (Nishi no Tani, ca. 0.5 ha; Fig. 1) and the eastern part with a wide drainage area (Higashi no Tani, ca. 0.3 ha). We studied the vegetation data for Nishi no Tani, which was expected to be oligotrophic because of its low-nutrient surface water conditions, thus resembling the donor marsh where many small plants were present. The study site is situated between 224 and $238 \mathrm{~m}$ a.s.l., with a gently declining slope (average inclination 6.7\%) from a pond toward the end of the marsh. The long-term meteorological data (1981-2010) show that the mean annual temperature is $13.9^{\circ} \mathrm{C}$ and the annual precipitation is $1,174 \mathrm{~mm}$ (Wake, Meteorological Agency). The surface rock type of this area is granite. In 1992, the forest vegetation surrounding the artificial marsh was
Conservation Center. The contour lines in the marsh area are erased; however, there is a gentle downward slope (average inclination $6.7 \%$ ) from the Nishitani-ike pond to the end of the marsh

dominated by pine (Pinus densiflora Siebold et Zucc.) mixed with oak (Quercus serrata Thunb.). In the years following the establishment of the artificial marsh, many pine trees died of pine wilt disease. To maintain adequate water supply and the same oligotrophic conditions in the artificial marsh as natural marshes in this district, which are covered with small plants and bordered with areas dominated by pine shrub trees, we periodically cut down dead pine, oak, and many shrubs, in addition to mowing the meadows.

Natural (donor) and artificial marsh

To construct the artificial marsh, the surfaces of abandoned paddies were reshaped by removing surface soil. A synthetic rubber sheet $(1.5 \mathrm{~mm}$ thick) was then laid over the whole surface and covered with a $50 \mathrm{~cm}$ layer of granitic sand (Hada et al. 1995). Many plants obtained for transplantation to the artificial marsh were collected from a donor marsh, in which natural plant communities showed low productivity and were dominated by Rhynchospora fujiiana Makino and $R$. faberi C.B. Clarke. This marsh was selected because it was scheduled for destruction during 
golf course construction, and some plants were replanted from the some other natural marshes. The donor marsh was located in an undulating meadow on a plateau ca. $60 \mathrm{~km}$ southwest of the Okayama Prefectural Nature Conservation Center (Fig. 1). The vegetation of the donor marsh had been studied during surveys in 1987-1988 within the framework of an environmental impact assessment for the new golf course (Washu-kaihatu Co. 1989). The natural structure of the floristic composition was destroyed during transplantation.

Sod, including mud-covered roots, was dug out with shovels during winter and transported in containers to the new site. Sod transplantation was complete by the next spring. Many fragments of vegetation were planted by hand at intervals of ca. $20 \mathrm{~cm}$, in the manner used for rice planting in paddies. After the main bulk of transplantation had been completed, rare plants (such as Habenaria radiata (Thunb.) Spreng. and Pogonia japonica Rchb.f.), which grew in the donor marsh, were planted out in the new marsh. Prior to planting out, these plants had been kept in a nursery garden for one year and allowed to propagate. We attempted to maintain the floristic composition of natural marshes in this district by planting propagules or seeds of selected species, including Lobelia sessilifolia Lamb., and by removing invading exotics such as Andropogon virginicus $\mathrm{L}$. and Solidago altissima $\mathrm{L}$. The surface water in the artificial marsh was supplied from the Heiseike pond (conductivity ca. $55 \mu \mathrm{S} \mathrm{cm}^{-1}$ ) by way of the Nishinotani-ike pond at a rate of $10 \mathrm{~m}^{3}$ day $^{-1}$ until water shortages made it necessary to dig a well in year 5 . The new water supply (flowing at $10 \mathrm{~m}^{3} \mathrm{day}^{-1}$ ) was oligotrophic (30-40 $\mu \mathrm{S} \mathrm{cm}^{-1}$ conductivity), promoting conditions in the artificial wetland that were suitable for vegetation found in oligotrophic marshes (such as the donor marsh).

Vegetation surveys and data analyses

Vegetation surveys were conducted at 34 plots (each $1 \times 1 \mathrm{~m})$ in the September of year 3 after transplantation to the artificial marsh, and we continued to monitor the fixed plots in the same month of years 5, 7, 9, and 12, with the addition of two plots in year 7 that were dominated by Moliniopsis japonica Hayata (Fig. 1). The cover and sociability of all species of vascular plants and the bryophyte (the only bryophyte was Sphagnum palustre L., which was introduced from a natural marsh near the artificial marsh) were recorded using the Braun-Blanquet method (Braun-Blanquet 1964; Mueller-Dombois and Ellenberg 1974; Suzuki et al. 1985).

Vegetation data collected each year from the fixed plots were classified into some communities and species groups by the Braun-Blanquet tabulation method, which was based on tables and graphical ordination plots constructed by detrended correspondence analysis (DCA; Gauch 1982; Hill 1979) using the program "mulvac" developed by Kobayashi (1995), with weighted covers expressed as cover class values $(\mathrm{r},+, 1,2,3,4,5$ to $1,2,3,4,5,6,7$; Mueller-Dombois and Ellenberg 1974). During the course of the analysis, the plots for each year and the donor marsh were initially ordinated using DCA, and were divided into several communities, with the floristic composition of each plot being identified using the stand index and species index for artificial grouping into communities to allow for comparison among sampling years. The floristic composition was used to identify plots that contained similar communities and to identify the direction of community transition during the course of the 12-year investigation. Once a community was identified, the same name and symbol were used in all years, with new community names and symbols added for plots that did not match existing community categories. Although we originally identified the communities by the dominant species for each investigation year, community names did not always match the names from the DCA analysis of floristic composition. For example, a summary table of the results shows that some communities with different dominant species were included in the same community (Table 2). Based on this information, we produced a summary table (MuellerDombois and Ellenberg 1974) showing the development of the identified community assemblies over the study period. In the course of this procedure, we ordinated communities that were identified in all investigation years as samples by using constancy class values of all species, which were modified to $1-5$ and corresponded to the constancy class values of I-V. By using the species arrangements obtained from the DCA ordination, we identified several different species groups and showed several species names in the DCA coordinate. We omitted some communities that have only single plots, because they were treated as outliers in DCA.

We classified all species occurring in the donor marsh and artificial marsh into groups based on their life-history characteristics and ecological habitats; specifically, annual or perennial, hygrophyte or aletophyte, woody plant, and climbing plant (Ohwi 1983; Nakaike 1992; Satake et al. 1981). We classified all species into six groups: (1) hygrophyte (annual), annual plants that grow in wetlands; (2) hygrophyte (perennial), perennial plants that grow in wetlands; (3) aletophyte (annual), annual plants that do not grow in wetlands; (4) aletophyte (perennial), perennial plants that do not grow in wetlands; (5) climbing plants; and (6) woody plants. Based on these categories, we calculated (1) the frequency of categorized species in each species group, and (2) the proportion of each group in each investigation year, including the donor marsh. In the 
Table 1 Transitions in community configurations within plots over the 12 years following transplantation

\begin{tabular}{|c|c|c|c|c|c|c|c|}
\hline Community & A & B & $\mathrm{Cl}$ & $\mathrm{C} 2$ & $\mathrm{D}$ & $\mathrm{E}$ & $\mathrm{F}$ \\
\hline $1993(3)^{\mathrm{a}}$ & $\begin{array}{l}\text { 93-A: } \\
\text { Ischaemum } \\
\text { aristatum } \\
\text { var. } \\
\text { glaucum } \\
\text { community: } \\
\text { 3, 10, } 11\end{array}$ & $\begin{array}{l}\text { 93-B: Isachne } \\
\text { globosa } \\
\text { community: } \\
\text { 5, 6, 12, 13, } \\
\text { 16, 26 }\end{array}$ & $\begin{array}{l}\text { 93-C1: Habenaria } \\
\text { radiata } \\
\text { community: } \\
\text { Rhynchospora } \\
\text { chinensis } \\
\text { subunit: } 18,24 \text {, } \\
25,27-29, \\
31-34\end{array}$ & $\begin{array}{l}\text { 93-C2: Habenaria } \\
\text { radiata community: } \\
\text { Eriocaulon } \\
\text { sikokianum subunit: } \\
1,2,4,7-9,14,15, \\
17,19-23,30\end{array}$ & & & \\
\hline 1995 (5) & $\begin{array}{l}\text { 95-A: } \\
\text { Ischaemum } \\
\text { aristatum } \\
\text { var. } \\
\text { glaucum } \\
\text { community: } \\
\text { 3, 10, } 11\end{array}$ & $\begin{array}{l}\text { 95-B: Isachne } \\
\text { globosa } \\
\text { community: } \\
\text { 5, 16, 26, } 34\end{array}$ & $\begin{array}{l}\text { 95-C1: Habenaria } \\
\text { radiata } \\
\text { community: } \\
\text { Lobelia } \\
\text { sessilifolia } \\
\text { subunit: } 8,9 \text {, } \\
13,18,23,25, \\
28,33\end{array}$ & $\begin{array}{l}\text { 95-C2: Habenaria } \\
\text { radiata community: } \\
\text { Rhynchospora faberi } \\
\text { subunit: } 1,2,4,6,7 \text {, } \\
12,14,15,17,19-22 \\
24,27,29-32\end{array}$ & & & \\
\hline 1997 (7) & $\begin{array}{l}\text { 97-A: } \\
\text { Ischaemum } \\
\text { aristatum } \\
\text { var. } \\
\text { glaucum } \\
\text { community: } \\
10,11\end{array}$ & $\begin{array}{l}\text { 97-B: } \\
\text { Lysimachia } \\
\text { vulgaris var. } \\
\text { davurica } \\
\text { community: } \\
16\end{array}$ & $\begin{array}{l}\text { 97-C1: Habenaria } \\
\text { radiata } \\
\text { community: } \\
\text { Cyperus haspan } \\
\text { subunit: } 13,15 \text {, } \\
18,23,26,28, \\
32,33\end{array}$ & $\begin{array}{l}\text { 97-C2: Habenaria } \\
\text { radiata community: } \\
\text { Eriocaulon } \\
\text { decemflorum var. } \\
\text { nipponicum subunit: } \\
\text { 1-9, 12, 14, 17, } \\
\text { 19-22, 24, 25, 27, } \\
29-31,34\end{array}$ & $\begin{array}{l}\text { 97-D: } \\
\text { Moliniopsis } \\
\text { japonica } \\
\text { community: } \\
35,36\end{array}$ & & \\
\hline 1999 (9) & $\begin{array}{l}\text { 99-A: } \\
\text { Ischaemum } \\
\text { aristatum } \\
\text { var. } \\
\text { glaucum } \\
\text { community: } \\
10,11\end{array}$ & $\begin{array}{l}\text { 99-B: } \\
\text { Lysimachia } \\
\text { vulgaris var. } \\
\text { davurica } \\
\text { community: } \\
16\end{array}$ & $\begin{array}{l}\text { 99-C1: } \\
\text { Rhynchospora } \\
\text { fujiiana } \\
\text { community: } \\
\text { Scirpus hotarui } \\
\text { subunit: } 5,13 \text {, } \\
\text { 18, 23, 28, } \\
\text { 32-34 }\end{array}$ & $\begin{array}{l}\text { 99-C2: Rhynchospora } \\
\text { fujiiana community: } \\
\text { Eriocaulon } \\
\text { decemflorum var. } \\
\text { nipponicum subunit: } \\
1-4,6-9,12,14,15 \text {, } \\
17,19-22,24-27, \\
29-31\end{array}$ & $\begin{array}{l}\text { 99-D: } \\
\text { Moliniopsis } \\
\text { japonica } \\
\text { community: } \\
35,36\end{array}$ & & \\
\hline 2002 (12) & $\begin{array}{l}\text { 02-A: } \\
\text { Ischaemum } \\
\text { aristatum } \\
\text { var. } \\
\text { glaucum } \\
\text { community: } \\
\text { 10, 11, } 26\end{array}$ & $\begin{array}{l}\text { 02-B: } \\
\text { Lysimachia } \\
\text { vulgaris var. } \\
\text { davurica } \\
\text { community: } \\
16\end{array}$ & $\begin{array}{l}\text { 02-C1: } \\
\text { Rhynchospora } \\
\text { fujiiana } \\
\text { community: } \\
\text { Eleocharis } \\
\text { wichurae } \\
\text { subunit: 5, 12, } \\
\text { 17, 18, 22-25, } \\
\text { 27-29, 33, 34 }\end{array}$ & $\begin{array}{l}\text { 02-C2: Rhynchospora } \\
\text { fujiiana community: } \\
\text { Dimeria ornithopoda } \\
\text { var. tenera subunit: } \\
1-4,6-9,13-15 \\
\text { 19-21, } 30\end{array}$ & $\begin{array}{l}\text { 02-D: } \\
\text { Moliniopsis } \\
\text { japonica } \\
\text { community: } \\
\text { 35, } 36\end{array}$ & $\begin{array}{l}\text { 02-E: } \\
\text { Lysimachia } \\
\text { fortunei } \\
\text { community: } \\
32\end{array}$ & $\begin{array}{l}\text { 02-F: Pinus } \\
\text { densiflora } \\
\text { shrub } \\
\text { community: } \\
31\end{array}$ \\
\hline
\end{tabular}

Each community was numbered by year and community code number. For example, the Habenaria radiata community: Rhynchospora chinensis subunit identified in 1993 was assigned the number 93-C1. Numbers after the community name indicate the numbers of plots assigned to the selected community

a Time after transplantation (years)

second calculation, the value was expressed as the relative cover, which was calculated as the total cover class value for a group divided by the total of all groups using weighted cover class values.

Water chemistry parameters $[\mathrm{pH}$ and electrical conductivity (EC)] were measured at the surface layer of the Nishitani-ike pond using a multi water quality checker (Horiba U-10) three times a month for fixed periods of time from 1993 onward. Based on this information, we calculated the average values for each year.

\section{Results}

Community identification and transitions over 12 years

The trajectories of community transition in the artificial marsh plots over the 12-year period are shown in Table 1 . In total, five different communities were isolated: community A: Ischaemum aristatum var. glaucum community; community B: Isachne globosa community, which changed to Lysimachia vulgaris var. davurica community at year 7; 
community C: $H$. radiata community, with the $R$. chinensis subunit designated as $\mathrm{C} 1$, and the Eriocaulon sikokianum subunit designated as $\mathrm{C} 2$; community $\mathrm{D}$ : the $M$. japonica community. Plots 10 and 11 were assigned to community A over the 12-year period. Additional plots were also intermittently assigned to community A; specifically, plot 3 in years 3 and 5 and plot 26 in year 12. In other years, plot 3 was assigned to community $\mathrm{C} 2$ in year 7 , and plot 26 shifted from community $\mathrm{C} 1$ to $\mathrm{B}$ and to $\mathrm{C} 2$ over the course of the study. There was an overall decrease in the number of plots assigned to community B; six plots were assigned to this community in year 3 , four plots in year 5 , and just one plot in year 7, with Lysimachia vulgaris var. davurica being the only component species of this community after year 7. This was because one of the plots that was dominated by Isachne globosa was occupied by L. vulgaris var. davurica, and the species occurring in the other plots was altered. From year 7 onward, other plots in community B shifted to communities $\mathrm{C} 1$ or $\mathrm{C} 2$. We defined community $\mathrm{B}$ as a new group that consisted of only one plot, even though the floristic composition was quite different to that previously recorded. Most of the plots assigned to communities $\mathrm{C} 1$ or $\mathrm{C} 2$ maintained this assignation or shifted from one to the other. Community D (dominated by M. japonica) was newly identified in year 7 after the introduction of M. japonica seeds, with plots 35 and 36 also being assigned to this community. Both community $\mathrm{E}$ (dominated by L. fortunei) and community $\mathrm{F}$ (dominated by the shrub $P$. densiflora) occurred in just one plot each, and were newly identified in year 12 .

Community assemblies are summarized in Table 2 . We extracted three community assemblies in the artificial marsh; specifically, the M. japonica community (community 1 ), the I. aristatum var. glaucum community (community 2), and the R. fujiiana community (communities 3-1 and 3-2). The R. fujiiana community comprised two subunits identified as the Eleocharis wichurae subunit (community 3-1) and the Dimeria ornithopoda var. tenera subunit (community 3-2). Each community was classified by a combination of species groups; community 1 was characterized by species groups 1,2 , and 3; community 2 by species groups 2 and 3; community 3-1 by species groups 3 , 4 , and 5 ; and community $3-2$ by species groups 3,5 , and 6 .

In Table 2, the life-history characteristics and ecological habitats of occurring species are identified. The proportions of each plant category for each species group are shown in Fig. 2. Species group 1 comprised perennial, and climbing, and woody plants. Species group 2 primarily included climbing and woody plants, a perennial plant and sphagnum, which is characteristic of mires and occasionally grows in the shade of woody plants in this district (Nishimoto 2008). Species group 3 comprised mainly hygrophyte perennials favoring marsh environments, in addition to some aletophyte perennials. Species groups 4-6 comprised many hygrophyte annuals and perennials, which are the main components of natural marshes in this district (Hada 1984). Species group 5 characterized community 3, with species groups 4 and 6 differentiating the two subunits of this community. Basically, species group 6 had a higher proportion of hygrophyte perennials than species group 4, which showed higher frequencies of aletophyte perennials. Species group 7 comprised hygrophyte perennials found only in the donor marsh. There was an increase in the proportion of aletophyte perennials (to about $50 \%$ ) in species group 5 and species group 4 , although aletophyte perennials were also found in groups 1 and 2, which were almost entirely composed of clonal perennials.

Changes in community relationships over the 12-year period, based on DCA ordination

Community assemblies (Fig. 3a) and species groups (Fig. 3b) were plotted on two sets of coordinates, which allowed the identification of relationships among communities over the 12-year study period. Communities of the donor marsh were clustered in the lower-left position, whereas communities of the artificial marsh were distributed widely across the plot. Along the first ordination axis of the DCA, the ordering of the communities was first the $M$. japonica community, then the I. aristatum var. glaucum community, and finally the $R$. fujiiana community. The two subunits of the $R$. fujiiana community were present along the second DCA axis; specifically, the Scirpus hotarui subunit with Juncus leschenaultii and the D. ornithopoda var. tenera subunit with $P$. japonica. The communities that were identified in each of the study years (as shown in Table 1) were clustered in a limited area of DCA coordinate space. However, the positions of the communities shifted slightly with each year, except for the I. globosa community, which was in community 3-2 in year 3 and community 3-1 in year 5 . In this case, while the I. globosa community was identified in years 3 and 5 , based on the dominance of this species, the results of the DCA showed that it could equally be placed in community 3 .

Based on the locations of species in coordinate space (Fig. 3b), the first DCA ordination axis represented a gradient shifting from SG1 and SG2, which were mainly composed of climbing (Rhynchosia volubilis and Lonicera japonica) and woody plants (Frangula crenata and Rhododendron reticulatum), through SG3 and SG5, which were composed of aletophytes and hygrophytes ( $R$. chinensis), to SG7, which was composed of hygrophytes of oligotrophic marshes (Platanthera tipuloides var. nipponica) comprising dense low growth of small sedges and other plants. The second DCA axis reflected a gradient from SG4, which was composed of aletophytes (Triadenum 
Table 2 Summary of the communities identified in the donor marsh and in the artificial marsh at five investigation years within the 12-year period following transplantation
Frequency of occurrence when there were more than 5 plots: $\mathrm{I}=1-20 \%, \mathrm{II}=21-40 \%$, $\mathrm{III}=41-60 \%, \mathrm{IV}=61-80 \%$, $\mathrm{V}=81-100 \%$. The frequency of occurrence when there were less than 5 plots: 1-4. $H A$ hydrophyte annual, $H P$ hydrophyte perennial, $A A$ aletophyte annual, $A P$ aletophyte perennial, $W$ woody plant, $C$ climbing plant, (2) originally in donor marsh, $\bigcirc$ transplant from other marshes. Some species of lower occurrences were omitted

\begin{tabular}{|c|c|c|c|c|c|c|c|c|c|c|c|c|c|c|c|c|c|c|c|c|c|}
\hline Community & & & & & & $\begin{array}{l}\text { is ja } \\
\text { pora } \\
\text { subu }\end{array}$ & & & & & & & $\begin{array}{l}\text { haen } \\
\text { scirp }\end{array}$ & & & & & & $\begin{array}{l}\text { Laucum } \\
\text { Dimeri }\end{array}$ & $\begin{array}{l}m \text { con } \\
\text { ia orr }\end{array}$ & rmmur \\
\hline & & & & 1 & & & & 2 & & & & & & & & - & 3 & & & & \\
\hline & & & & & & & & & & & & & L & 1 & & & & & 2 & & \\
\hline Running number & & & 1 & & & 4 & 5 & 6 & & & & 10 & 11 & 12 & 13 & 14 & 15 & 16 & $17 \quad 18$ & $8 \quad 19$ & 920 \\
\hline Community number & & & $\stackrel{99-}{\mathrm{D}}$ & & & A7- & $\stackrel{99-}{A}$ & $\begin{array}{c}95- \\
A\end{array}$ & $\stackrel{02-}{A}$ & $\begin{array}{c}93- \\
A\end{array}$ & & $\begin{array}{lll}-0 & 02- \\
1 & c 1\end{array}$ & $\begin{array}{l}99- \\
c_{1}\end{array}$ & $\begin{array}{l}95- \\
C_{1}\end{array}$ & $\begin{array}{c}93- \\
{ }_{C 1}\end{array}$ & $\begin{array}{c}95- \\
\mathrm{B} \\
\end{array}$ & & $\begin{array}{l}02-9 \\
\mathrm{C}^{2} 2\end{array}$ & & & $\begin{array}{l}3-93- \\
32\end{array}$ \\
\hline Number of samples & & & 2 & 2 & 2 & 2 & 2 & 3 & 3 & 3 & 8 & 313 & 8 & 8 & 10 & 4 & 23 & & & & 715 \\
\hline Species group 1 & & & & & & & & & & & & & & & & & & & & & \\
\hline Moliniopsis japonica Hayata & HP & & 2 & & & - & . & & & 1 & & . & . & . & I & & I & I & - I & . & - \\
\hline Rhododendron reticulatum D.Don & W & 0 & 2 & 2 & 1 & . & - & - & . & . & . & . & - & - & . & - & . & - & - . & . & - \\
\hline Thelypteris palustris Schott & AP & 0 & 1 & 1 & 2 & . & - & - & . & - & . & I & I & - & & - & $\mathrm{r}$ & I & . & . & . \\
\hline Rhamnus crenata Sieb. et Zucc. & W & & 1 & 1 & - & - & - & - & . & . & . & - & . & - & - & . & - & - & - & - & - \\
\hline Rhynchosia volubilis Lour. & c & & 1 & - & . & . & - & - & - & . & . & . & . & - & . & - & . & . & . & . & . \\
\hline Species group 2 & & & & & & & & & & & & & & & & & & & & & \\
\hline Lonicera japonica Thunb. & $\mathrm{C}$ & 0 & 1 & 1 & & 2 & 1 & 1 & 1 & - & . & - & . & - & - & - & . & - & - & . & - \\
\hline Sphagnum palustre $\mathrm{L}$. & HP & 0 & 2 & 2 & 2 & 2 & 2 & 2 & 3 & 1 & . & . & . & - & . & - & . & I & . & . & I \\
\hline Rosa paniculigera Makino & $\mathrm{c}$ & 0 & - & . & 1 & 1 & 1 & 1 & 2 & 1 & & I & . & - & . & . & $\mathrm{r}$ & . & . & . & . \\
\hline Ilex crenata Thunb. & w & ()) & 2 & 1 & 1 & 1 & 1 & 1 & & . & & . & - & - & . & - & $\mathrm{r}$ & . & $\mathrm{r}$ & . & - \\
\hline Species group 3 & & & & & & & & & & & & & & & & & & & & & \\
\hline Mosla dianthera (Hamilt.) Maxim. & $\mathrm{AA}$ & & 1 & - & 1 & 1 & 1 & • & 2 & 1 & $\mathrm{~V}$ & $\mathrm{IV}$ & $\mathrm{V}$ & $\mathrm{V}$ & $\mathrm{V}$ & 4 & IV & IIII I & IV IV & $\mathrm{V}$ III & II II \\
\hline Equisetum arvense $\mathrm{L}$. & AP & 0 & 2 & 2 & 2 & 2 & 2 & 3 & 2 & 2 & IV & $\mathrm{V}$ IV & $\mathrm{V}$ & II & I & 1 & $\mathrm{~V}$ & IV & IV II & II III & II II \\
\hline Eupatorium lindleyanum DC. & HP & (c) & 2 & 2 & 2 & 2 & 2 & . & 2 & 1 & IV & V IV & $\mathrm{V}$ & IV & IV & 2 & $\mathrm{~V}$ & $\mathrm{~V}$ & V IV & V III & II II \\
\hline Isachne globosa (Thunb.) Kuntze & HP & () & 2 & 2 & 2 & 2 & 2 & 2 & 3 & 3 & IV & $\mathrm{V} \mathrm{V}$ & $\mathrm{V}$ & $\mathrm{V}$ & IV & 4 & $\mathrm{~V}$ & $\mathrm{~V}$ & $\mathrm{~V} \mathrm{~V}$ & $V$ III & II $\mathrm{V}$ \\
\hline Cirsium sieboldii Miq. & HP & (2) & 1 & - & - & 1 & 1 & 1 & 2 & 2 & & V III & IV & II & II & 3 & II & II & I I & I II & I II \\
\hline Eleocharis wichurae Bocklr. & HP & (2) & - & 1 & . & 2 & 1 & 1 & 1 & 2 & I & I IV & IV & IV & I & 1 & III & I & II I & I III & II I \\
\hline Persicaria nipponensis H.Gross & $\mathrm{HA}$ & & 1 & 1 & - & . & - & 1 & - & 1 & & I IV & $\mathrm{V}$ & IV & II & 2 & III & I & II III & II I & I II \\
\hline Arundinella hirta (Thunb.) C.Tanaka & AP & () & - & . & 1 & 1 & 1 & 1 & 2 & 2 & & I II & II & IV & II & 1 & I & IV & II III & II III & II I \\
\hline Ischaemum aristatum L. var. glaucum T.Koyama & HP & 0 & 2 & 2 & 1 & 2 & 2 & 3 & 2 & 3 & & - IV & IV & . & I & 1 & IV & $\mathrm{V}$ & III II & II II & $I \cdot$ \\
\hline Lycopus maackianus Makino & HP & 0 & 2 & 1 & 1 & 2 & 2 & 3 & 2 & 3 & I & I III & II & - & - & 2 & II & I & I II & I & I I \\
\hline Miscanthus sinensis Anders. & $\Lambda P$ & 0 & 1 & . & 2 & 1 & 1 & 2 & 1 & 1 & & - II & I & II & I & 1 & I & I & I II & . & . \\
\hline Lobelia sessilifolia Lamb. & HP & 0 & - & - & 2 & . & 1 & . & 3 & - & I & I III & III & II & II & - & $\mathrm{r}$ & I & $\mathrm{r} \quad \mathrm{I}$ & . & - . \\
\hline Hypericum japonicum Thunb. & $\mathrm{HA}$ & 0 & . & . & . & . & 1 & - & 1 & - & I & I III & I & & II & . & III & II & II II & . & . \\
\hline Eupatorium chinense L. var. oppositifolium Murata $e t$ H.Koyama & AP & & 1 & 1 & . & 2 & . & 3 & . & . & . & . & II & . & . & . & I & I & II I & . & . \\
\hline Viola verecunda A.Gray var. subaequiloba F.Maek. & AP & 0 & 2 & 2 & 2 & 1 & 1 & 2 & 2 & 3 & & I & I & I & $\cdot$ & 1 & I & I & I II & III & II I \\
\hline Carex dispalata Boott & AP & & 2 & 1 & 1 & . & - & 1 & - & 1 & . & I & - & . & I & - & II & III & II II & I & I. \\
\hline Paederia scandens Merr. & c & & - & - & 1 & 1 & 2 & 1 & 1 & 1 & & I & - & - & . & 1 & & I & $\mathrm{r} \quad \mathrm{I}$ & I & I. \\
\hline Eleocharis tetraquetra Nees & HP & & 1 & . & - & . & 1 & . & 1 & . & . & II & I & . & . & - & II & II & - $\cdot$ & . & - \\
\hline Lysimachia vulgaris $\mathrm{L}$. var. davurica R.Kunth & HP & & - & - & . & 1 & 1 & - & 1 & - & . & I & - & - & . & 1 & $\mathrm{r}$ & I & - $\cdot$ & . & . \\
\hline Juncus effusus L. var. decipiens Buchen. & AP & & $\cdot$ & 1 & $\cdot$ & $\cdot$ & $\cdot$ & . & . & - & & . & II & $\cdot$ & $\cdot$ & 2 & $\mathrm{r}$ & . & I II & II I & I. \\
\hline Species group 4 & & & & & & & & & & & & & & & & & & & & & \\
\hline Scirpus hotarui Ohwi & $\mathrm{HA}$ & ()) & . & - & . & - & - & . & 1 & - & I) & $\mathrm{V}$ II & IV & $\cdot$ & I & - & . & . & I I & I & I I \\
\hline Juncus leschenaultii Gay & AP & & . & - & - & . & - & - & . & . & & $V$ II & IV & I & I & - & II & I & II II & I & I II \\
\hline Cyperus haspan $\mathrm{L}$. & AP & & . & . & - & . & - & . & - & . & & $V$ III & III & II & II & 1 & II & II & I I & . & - II \\
\hline Persicaria sieboldii (Meisn.) Ohki & $\mathrm{AA}$ & 0 & - & . & . & . & . & - & 1 & . & & I III & II & II & I & 1 & II & - & I I & . & I \\
\hline Cyperus sanguinolentus Vahl & HP & & . & . & - & . & - & - & . & . & & I II & I & IV & II & - & II & . & I I & - & - I \\
\hline Hosta longissima Honda var. brevifolia F.Maek. & HP & 0 & . & . & . & . & - & . & - & . & $\mathrm{I}$ & I I & II & II & I & - & I & I & I $\cdot$ & I & . \\
\hline Triadenum japonicum Makino & HP & 0 & . & . & . & - & - & . & . & - & 1 & I I & I & I & . & - & . & I & . & . & . \\
\hline Hydrocotyle maritima Honda & AP & & . & . & . & - & - & . & - & . & I & $\mathrm{I}$. & III & . & . & 1 & I & . & $\mathrm{r}$ & . & . \\
\hline Ixeris dentata (Thunb.) Nakai & AP & & $\cdot$ & . & . & . & - & - & . & . & . & I & II & . & . & . & II & I & $\mathrm{r}$ & . & . \\
\hline Species group 5 & & & & & & & & & & & & & & & & & & & & & \\
\hline Rhynchospora chinensis Nees et Meyen & HP & (2) & . & - & - & . & - & - & - & . & $\bar{I}$ & I II & II & II & IV & 1 & II & I & II II & I I & I \\
\hline Rhynchospora fujiiana Makino & $\mathrm{HP}$ & () & - & . & . & . & - & - & - & 1 & II & II $\mathrm{V}$ & $\mathrm{V}$ & III & IV & 2 & IV & IV & III III & II III & II I \\
\hline Rhynchospora faberi C.B.Clarke & HP & ()) & . & - & - & . & - & 1 & . & 1 & I & I IV & II & II & III & - & $\mathrm{V}$ & IV & IV IV & $V$ III & II IV \\
\hline Hololeion krameri Kitam. & HP & ()) & . & 2 & . & 1 & - & . & 2 & 2 & $\mathrm{r}$ & $\mathrm{V}$ & $\mathrm{V}$ & $\mathrm{V}$ & $\mathrm{V}$ & 2 & $\mathrm{~V}$ & IV & V IV & & II $\mathrm{V}$ \\
\hline Habenaria radiata (Thunb.) Spreng. & HP & ()) & . & . & . & . & . & 1 & . & 1 & & II III & II & IV & IV & 3 & $\mathrm{~V}$ & $\mathrm{~V}$ & $\mathrm{~V} \mathrm{~V}$ & III & I $\mathrm{V}$ \\
\hline Utricularia bifida $\mathrm{L}$. & HP & (2) & . & - & . & - & - & . & - & 1 & I & I II & $\cdot$ & II & IV & 1 & III & II & IV III & II III & II $\mathrm{V}$ \\
\hline Sacciolepis indica $(\mathrm{L}$.$) Chase$ & $\mathrm{HA}$ & & 1 & . & . & . & - & 1 & . & & & $\mathrm{V} \mathrm{V}$ & $\mathrm{V}$ & IV & $\mathrm{V}$ & & $\mathrm{V}$ & IV & $\mathrm{V} \mathrm{V}$ & & I III \\
\hline Eriocaulon decemflorum Maxim.var. nipponicum (Maxim.) Nakai & $\mathrm{HA}$ & & - & - & - & . & - & 1 & - & 1 & & I IV & I & IV & III & - & IV & IV & IV IV & 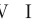 & I IV \\
\hline Cyperus brevifolius (Rottb.) Hassk. var. leiolepis T.Koyama & AP & & $\cdot$ & $\cdot$ & $\cdot$ & • & $\cdot$ & • & 1 & $\cdot$ & & $V$ IV & II & III & III & & III & II $\mathrm{l}$ & IV IV & V I & I I \\
\hline Epilobium pyrricholophum Franch. et Sav. & AP & & 1 & . & . & . & 1 & - & 2 & . & I & $\mathrm{V}$ IV & $\mathrm{V}$ & IV & IIII & 2 & III & III & III III & & I III \\
\hline Fimbristylis subbispicata Nees et Mey. & HP & 0 & - & . & - & . & - & - & . & - & & II $\mathrm{V}$ & IV & II & I & 1 & $\mathrm{~V}$ & $\mathrm{~V}$ & IV III & & - II \\
\hline Eleocharis congesta D.Don & $\mathrm{HA}$ & & . & . & - & . & 1 & 1 & - & 2 & $\mathrm{r}$ & I & III & IV & II & 3 & III & I & IV I & I III & II II \\
\hline Eriocaulon sikokianum Maxim. & $\mathrm{HA}$ & 0 & - & - & 1 & . & 1 & . & 1 & 2 & & II II & II & IV & I & & III & II & III III & & I III \\
\hline Kummerowia striata (Thunb.) Schindl. & $\mathrm{AA}$ & & . & . & - & . & - & 1 & . & 1 & I & I III & II & II & I & 2 & IV & IV & IV III & & - IV \\
\hline Andropogon virginicus $\mathrm{L}$. & AP & ()) & - & . & . & . & - & - & - & 1 & 1 & I II & II & I & III & 1 & III & II & III IV & & I III \\
\hline Cyperus globosus All. & AP & & - & . & . & - & - & - & . & - & I & II & III & . & I & - & III & IV & III . & I & I I \\
\hline Arthraxon hispidus (Thunb.) Makino & $\mathrm{AA}$ & & . & . & . & . & - & 1 & - & - & I & $\mathrm{I} \mathrm{V}$ & III & II & III & 1 & IV & III & III III & & $\cdot$ \\
\hline Species group 6 & & & & & & & & & & & & & & & & & & & & & \\
\hline Dimeria ornithopoda Trin. var. tenera Hack. & $\mathrm{HA}$ & () & • & - & - & . & - & . & . & - & 1 & II & I & IV & IV & - & $\mathrm{V}$ & IV & $\mathrm{V} \mathrm{V}$ & III & II $\mathrm{V}$ \\
\hline Pogonia japonica Rchb.f. & HP & (2) & $\cdot$ & - & • & $\cdot$ & $\cdot$ & - & · & • & I & I $\cdot$ & II & $\cdot$ & $\cdot$ & - & II & IV & II II & I I & III \\
\hline Juncus papillosus Franch. et Sav. & $\mathrm{HP}$ & (2) & . & - & . & - & - & - & - & 1 & & - I & II & II & I & - & & I & II I & I III & II II \\
\hline Haloragis micrantha (Thunb.) R.Br. & AP & (2) & . & - & . & - & 1 & - & - & - & . & · & II & II & II & 1 & III & III & III III & & I III \\
\hline Utricularia caerulea $\mathrm{L}$. & $\mathrm{HP}$ & 0 & - & - & - & - & . & - & - & - & . & I & · & . & II & - & III & II & IV IV & & I IV \\
\hline Drosera rotundifolia $\mathrm{L}$. & HP & (2) & . & - & - & - & - & - & - & - & . & . & I & - & II & - & II & III & II III & & II $\mathrm{V}$ \\
\hline Species group 7 & & & & & & & & & & & & & & & & & & & & & \\
\hline Schoenus apogon Roem. et Schult. & $\mathrm{HA}$ & ()) & - & - & - & - & - & - & - & - & . & - & - & - & - & - & - & - & - & & • \\
\hline Rhynchospora rubra (Lour.) Makino & HP & () & - & - & - & - & - & - & - & • & & - & - & - & - & - & - & - & - & • & - \\
\hline Platanthera tipuloides Lindl. var. nipponica Ohwi & $\mathrm{HP}$ & (a) & - & - & - & - & - & - & - & - & & - & - & . & $\cdot$ & - & . & - & . & & - \\
\hline
\end{tabular}

japonicum and Hydrocotyle maritima), through SG5 to SG6, which had increased proportions of hygrophytes of oligotrophic marshes (Drosera rotundifolia).

Transition of species components based on habitat ecology

In Fig. 4, changes in the proportions of the six categorized species groups over a 12-year period are shown in comparison to that of the donor marsh at the outset, which represents the target composition for the artificial marsh. Hygrophyte (perennial) species comprised $74 \%$ of the total species in the donor marsh, in comparison to $51 \%$ of the species in years 3 and 5 in the artificial marsh, which gradually increased to $58 \%$ in years 7,9 , and 12 . The proportion of hygrophyte (annual) species was $13 \%$ in the donor marsh, in comparison to $22 \%$ in year 3 in the artificial marsh; the proportion decreased as the hygrophyte 


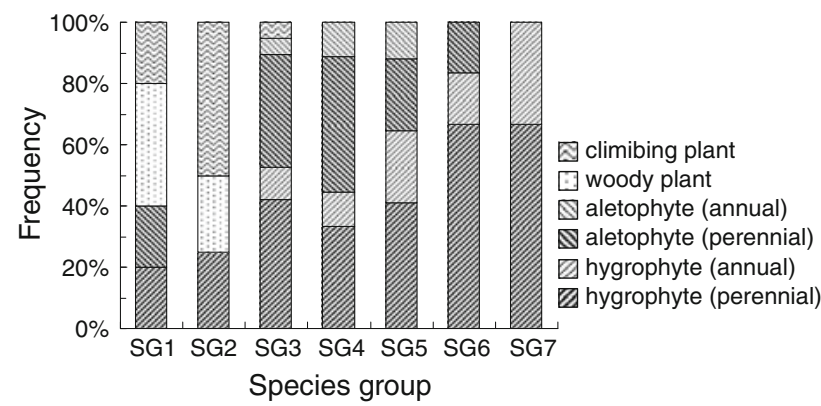

Fig. 2 Proportions of each plant category (plant type and original habitat, hygrophyte or aletophyte) in each species group

(perennial) species increased in year 7, and further declined to match that of the donor marsh in years 9 and 12 .

Aletophyte (perennial) species accounted for only $10 \%$ of the total vegetation cover in the donor marsh, but represented $21 \%$ of the vegetation cover in year 5 in the artificial marsh, $14 \%$ in years 7 and 9 , and increased slightly to $17 \%$ in year 12 . Aletophyte (annual) species did not grow in the donor marsh, but it represented about $13 \%$ of the vegetation cover in the artificial marsh immediately after transplantation, with a slight decline to $10 \%$ by year 12.

Several types of climbing and woody plants accounted for 2 and $1 \%$ of the donor marsh cover, respectively. Climbing plants were not found in the artificial marsh until year 7, but the proportion of them increased slightly to comprise $3 \%$ of the total cover in year 12 . However, woody plants represented $0.3 \%$ of the cover in year 3 , and

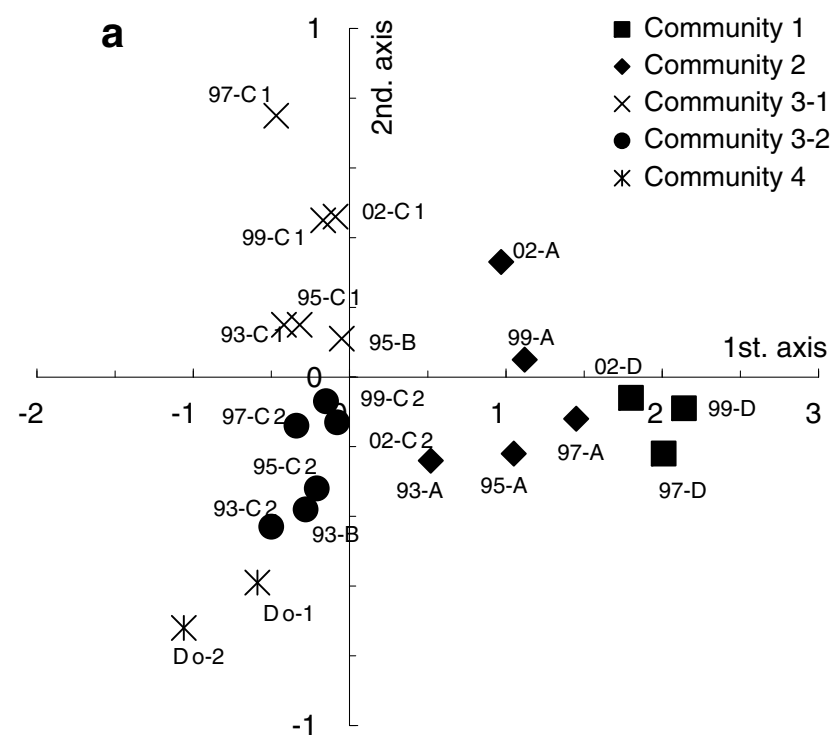

Fig. 3a-b Arrangement of vegetation types (a) and species groups (b) in DCA coordinate space. Symbols in a indicate the community numbers shown in Table 2. Species list: Dr, Drosera rotundifolia; Fc, Frangula crenata; Hm, Hydrocotyle maritima; Mj, Moliniopsis

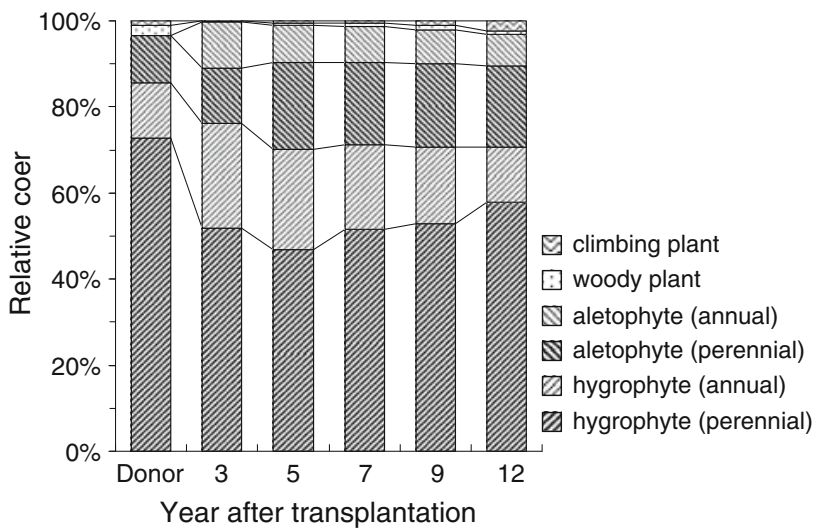

Fig. 4 Proportional cover of the six species groups in the donor marsh at the outset as a target, and in the artificial marsh for years 3 , $5,7,9$, and 12 after transplantation

remained at less than $1 \%$ of the total cover throughout the 12-year period.

Change in chemical status of the surface water

In Fig. 5, changes in groundwater $\mathrm{pH}$ and electrical conductivity in the artificial marsh from 1993 to 2002 are shown. The $\mathrm{pH}$ value was around 6 in year 3 , and gradually decreased to 5 in year 12 . In comparison, electrical conductivity remained at $45-50 \mu \mathrm{S} \mathrm{cm}{ }^{-1}$ until year 6 , and then suddenly decreased to around $35 \mu \mathrm{S} \mathrm{cm}^{-1}$ at the start of year 7 , which was two years after the construction of the well in the artificial marsh.

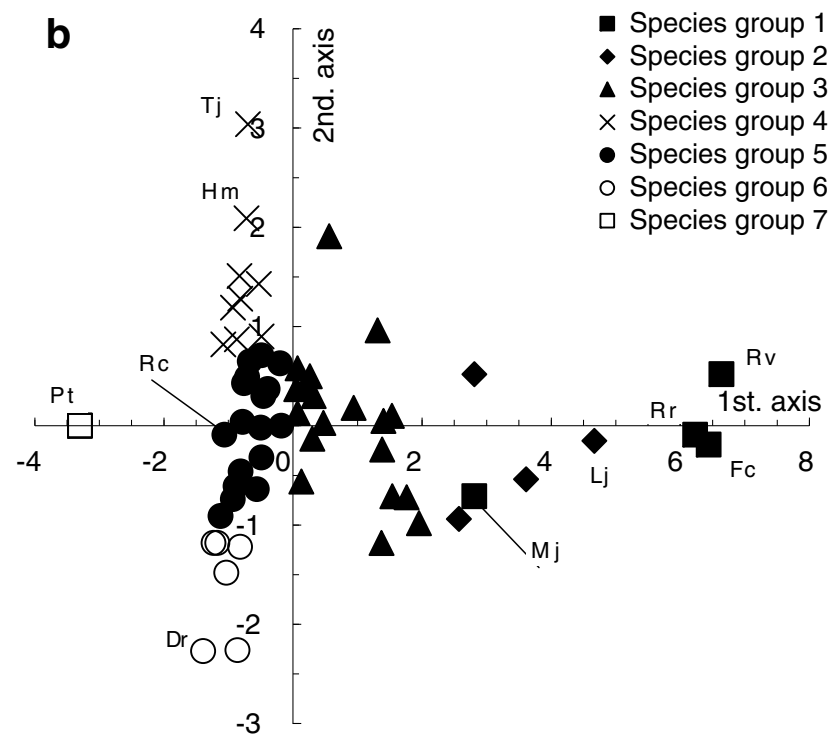

japonica; Pt, Platanthera tipuloides var. nipponica; Rv, Rhynchosia volubilis; $\mathrm{Lj}$, Lonicera japonica; $\mathrm{Rr}$, Rhododendron reticulatum; $\mathrm{Rc}$, Rhynchospora chinensis; $\mathrm{Tj}$, Triadenum japonicum 


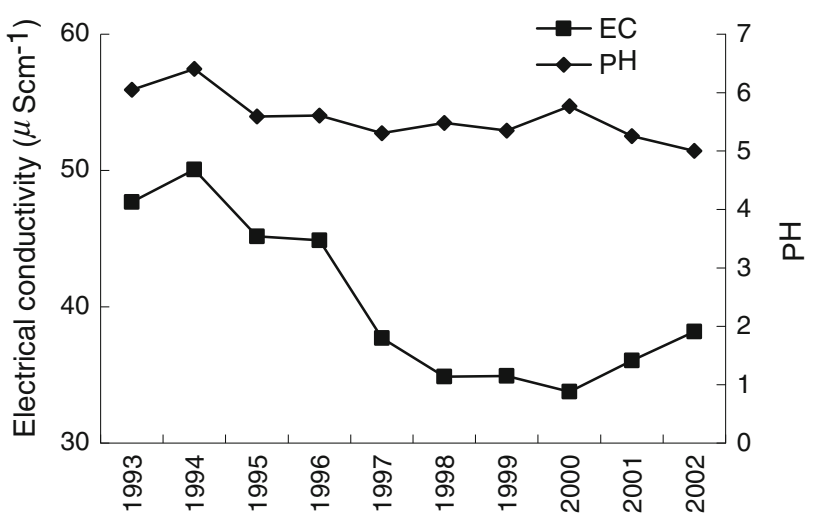

Fig. 5 Transition of water chemistry in the artificial marsh over a ten-year period

\section{Discussion}

Transition of plant communities and species along the vegetation gradient

The $R$. chinensis association is characterized by $R$. chinensis and I. aristatum var. glaucum, and is found on mineral oligotrophic sites at lowland areas in the Chugoku District of Japan (Hada 1984). According to the floristic composition, the donor marsh communities belonged to this association, which is typical of oligotrophic sites. The main community component in the artificial marsh during the study period was probably derived from the donor floristic composition that was transferred to the restoration site. However, other communities that were identified in the artificial marsh differed from those found in the donor marsh. The change in dominant species, with increasing proportions of annuals and perennials of hygrophytes and aletophytes versus decreasing proportions of hygrophyte perennials, reflected an increase in the dissimilarity of the two marshes.

Barendregt et al. (1995) suggested that wetland conservation depends not only on the water level but also on the qualitative aspects of hydrology. In our study, destruction of the original structural characteristics of vegetation from the donor marsh after transplantation appeared to initiate a rearrangement of species along hydrological gradients. Many species may be arrayed along these gradients. Some species that invaded as seeds from areas adjacent to the artificial marsh (or were present in the seed bank transferred from the donor marsh) sprouted in openings among the transplanted segments of vegetation. For example, I. aristatum var. glaucum originally grew in an area adjacent to the donor marsh, which resulted in its introduction and adaptation to arid conditions. This species became dominant at arid sites not reached by groundwater in the artificial marsh in the early stages after transplantation, due to a shortage of water until a well was dug in year 5. The I. aristatum var. glaucum community, which was present from years 3 to 12 , usually developed at sites where the surface dried out in summer, and when low precipitation and high temperatures prevailed; however, climbing and woody plants became dominant at sites where the water supply became insufficient on a constant basis. Subsequently, climbing and woody plants invaded these sites.

I. globosa, which is a species that is found in the donor marsh, became dominant in newly created muddy sites of the artificial marsh in the early stage of development. Initially, the I. globosa community differed markedly in floristic composition from the $H$. radiata community (93-B and 95-B in Fig. 3) due to the dominance of I. globosa. However, after year 7, almost all of the plots of the $I$. globosa community transformed to the $H$. radiata community, except for one plot. The I. globosa community was distributed on bare sites, because its stolons could easily spread in the first stage due to the disturbed state of the land. L. vulgaris var. davurica was able to easily invade one of the sites covered with I. globosa through the extension of rhizomes, and occupied it from year 7 onward. Kotowski et al. (2006) demonstrated that productivity gradients and their influence on competition intensity are of primary importance in structuring vegetation patterns. Chronological and spatial transitions from one species to another are caused by competition for light. L. vulgaris var. davurica was able to grow upward, consequently engulfing I. globosa.

The $H$. radiata community that developed from year 3 onward corresponded to the floristic composition of the donor marsh, and became widespread in the artificial marsh. However, this community was dominated by $R$. fujiiana in year 7 , and had an inherited floristic composition. Although the floristic composition differed slightly from that of the donor marsh, the main community in the artificial marsh may eventually develop toward resembling the donor marsh floristic composition. During the study period, some plots assigned to community $\mathrm{C} 1$ changed to community $\mathrm{C} 2$, and vice versa (Table 1 ). Such shifts indicate that sites in the artificial marsh were not stable.

The M. japonica community, which was not found in the donor marsh, was identified as a component of the artificial marsh from year 7 onward. Clearly, it took many years for seeds (originating from other marshes) of this community type to establish a new assemblage in the artificial marsh. The $M$. japonica community was situated on the right side of the first DCA axis (Fig. 3a), indicating that it developed on sites where climbing and woody plants grew (Fig. 3b).

Based on the arrangement of species along the DCA axes, two environmental factors may be related to species distribution, and hence community structure, at the artificial marsh study site, specifically: (1) a dry-wet moisture 
gradient from dry meadow conditions, with shrubs, to marsh conditions, and (2) a successional gradient from disturbed conditions to the establishment of the floristic composition of the marsh.

An important factor accounting for the increased proportion of hygrophyte (perennial) species in the artificial marsh at the start of year 7, and continued gradual increase until year 12, may be the provision of good-quality water, which came from low EC (i.e., $30-40 \mu \mathrm{S} \mathrm{cm}^{-1} \mathrm{EC}$ ), from the well from year 5 onwards. Another important factor was the continual weeding of unsuitable plants from the artificial marsh. Yabe et al. (2002) pointed out that immigrant species (or weeds) and many kinds of woody plants are most likely to immigrate to arid sites where the groundwater level is below $-7.5 \mathrm{~cm}$. The groundwater level could be kept suitable for growing hygrophyte perennials. However, secondary succession was a more important factor. Yabe and Nakamura (2010) also pointed out that the rapid increase in total species might be explained by the change of life forms in the early stage of secondary succession.

However, the results of measurements on the water chemistry of EC and $\mathrm{pH}$ may not entirely explain the differences in floristic composition in the communities. Unfortunately, there was insufficient information on water chemistry to discuss differences in the transitions of communities and their assemblies with respect to ecological gradients using nutrient richness based on $\mathrm{N}$ and $\mathrm{P}$.

Annual hygrophytes and aletophytes were prolific at bare sites that had newly formed during the first stage of artificial marsh establishment. However, only the proportions of annual hygrophytes decreased as perennial plant cover increased in year 7 , with this decrease continuing into years 9 and 12. The seed bank of annual aletophyte species in the soil made it very difficult to remove these species. Thus, extra weeding effort is required to remove these species over extended periods of time. Matthews and Endress (2010) demonstrated that annual species were replaced by clonal perennials, with a decline in colonization rates over time. However, based on our observations, we suggest that removing aletophytes is better for the predominance of hygrophyte annual species, because we should avoid forming a seed bank from which aletophyte annual species would sprout after disturbance by large mammals.

A decline in the proportion of perennial aletophytes was not recorded, even when plants such as A. virginicus, which grew in dry areas adjacent to forests and in the artificial marsh, were removed each year. Based on these results, we conclude that the widespread occurrence of perennial aletophytes limited the increases in the proportion of perennial hygrophytes.
Climbing plants increased continually, which was probably because of the dryness of the artificial marsh area adjacent to forest. It is possible that the water volume from the well may not have been adequate to moisten all the soil in the marsh, while forest trees would also have consumed very large volumes of water through their extensive root systems. Mitsch and Wilson (1996) demonstrated that evaluating the success of mitigation projects requires scientific observations over at least a 15-20-year period (rather than five years). In corroboration, Nishimura et al. (2009) showed that the original vegetation had not returned to peat-cutting sites even after 30 years of observation. Our study demonstrates that unnecessary plants should be periodically removed to facilitate the correct development of artificial marshes to reflect that of the original natural marshes, in parallel to maintaining suitable levels of water quality and quantity.

\section{Transplantation for marsh conservation}

Balcombe et al. (2005) noted that restoration sites tend to have more pioneer species and non-native dominants, and that compositional differences from donor sites become smaller as restoration sites age. At our restoration site, we did not uniformly reproduce the donor communities at the new location, because different site characteristics emerged after transplantation as a result of small-scale heterogeneity in hydrology and soil conditions. These variations were attributable to the destruction of the structure of donor vegetation, the provision of unsuitable water, and water shortages before the well was dug. Therefore, unless we are able to maintain low-nutrient surface water and remove unfavorable species, the compositional characteristics of the donor marsh may change uncontrollably over time. To prevent increases in the proportion of annual plants after transplantation, especially aletophytes, spacing in the artificial marsh should closely reflect that in the natural marsh, and low-nutrient conditions should be maintained. In conclusion, when the destruction of a natural marsh is unavoidable, the structure and floristic composition of the original vegetation should be recreated in an artificial marsh, and unsuitable plants should be regularly removed until a natural and sustainable equilibrium is established.

Acknowledgments We thank members of Washu-kaihatu Co. for their help in transporting the collected plants from the donor marsh to the Okayama Prefectural Nature Conservation Center. We also thank students of Okayama University of Science and volunteer members of the Center who helped with the weeding of unsuitable plants from the artificial marsh.

Open Access This article is distributed under the terms of the Creative Commons Attribution Noncommercial License which permits any noncommercial use, distribution, and reproduction in any medium, provided the original author(s) and source are credited. 


\section{References}

Atkinson RB, Perry JE, Cairns J (2005) Vegetation communities of 20-year-old created depressional wetlands. Wetlands Eco Manag 10:469-478

Balcombe CK, Anderson JT, Fortney RH, Rentch JS, Grafton WN, Kordek WS (2005) A comparison of plant communities in mitigation and reference wetlands in the Mid-Appalachians. Wetlands 25:130-142

Barendregt A, Wassen MJ, Schot P (1995) Hydrological systems beyond a nature reserve, the major problem in wetland conservation of Naardermeer (The Netherlands). Biol Conserv 72:391-405

Bootsman MC, Wassen MJ (1996) Environmental condition and fen vegetation in three lowland mires. Vegetation 127:173-189

Braun-Blanquet J (1964) Pflanzensoziologie, 3rd edn. Springer, Wien

Choi YD (2004) Theories for ecological restoration in changing environment: toward "futuristic" restoration. Ecol Res 19:75-81

Gauch HG (1982) Multivariate analysis in community ecology. Cambridge University Press, New York

Gore AJP (ed) (1983) Ecosystems of the world, vol 4B. Mires: swamp, bog, fen and moor; regional studies. Elsevier, Amsterdam

Gorham E (1956) The ionic composition of some bog and fen waters in the English Lake District. J Ecol 44:142-152

Hada Y (1984) Phytosociological studies on the moor vegetation in the Chugoku district, S.W. Honshu, Japan. Bull Hiruzen Res Inst Okayama Univ Sci 10:73-110

Hada Y (1993) Transportation of the natural marsh: an experiment on avoiding loss of species during development in Okayama Prefecture. Nikkei Constr 90:74-78 (in Japanese)

Hada Y (1997) The transplantation of natural marsh and creation of biotopes during highway development. Road Nat (Japan Highway Landscape Association) 95:36-39 (in Japanese)

Hada Y, Nishimoto T, Mitsumoto S (1995) Report of Marsh Land Garden, Okayama Prefectural Nature Conservation Center, Chugoku Dist., Japan. 1. Concept of land reclamation and method of plantation. Bull Okayama Pref Nature Cons Center 3:41-56 (in Japanese with English summary)

Hill MO (1979) DECORANA - a FORTRAN program for detrended correspondence analysis and reciprocal averaging. Cornell University, Ithaca

Iwase T (2001) 1. Vegetation change in Mobara-Yazumi Wetlands. 2. Conservation projects on the wetlands and present situation of the communities in the wetlands. In: Chiba Historical Material Research Foundation (ed) Natural history of Chiba Prefecture: plant in Chiba Prefecture, vol 2: vegetation. Chiba Pref, pp 384-391 (in Japanese)

Kentula ME, Sifneos JC, Good JW, Rylko M, Kunrz K (1992) Trends and patterns in Section 404 permitting requiring compensatory mitigation on Oregon and Washington, USA. J Environ Manage 16:109-119

Kobayashi S (1995) Multivariate analysis in community. Aoki-Shobo, Tokyo (in Japanese)

Kotowski W, Thorig W, van Diggelen R, Wassen MJ (2006) Competition as a factor structuring species zonation in riparian fens-a transplantation experiment. Appl Veg Sci 9:231-240

Lamers LPM, Smolders JP, Poelfofs JGM (2002) The restoration of fens in the Netherlands. Hydrobiologia 47:107-130

Large ARG, Mayes WM, Newson MD, Parkin G (2007) Using longterm monitoring of marsh hydrology and vegetation to underpin wetland restoration strategies. Appl Veg Sci 10:417-428

Lloyd JW, Tellam JH, Rukin N, Lerner DN (1993) Wetland vulnerability in East Anglia: a possible conceptual framework and generalised approach. J Environ Manage 37:87-102
Malson K, Backeus I, Rydin H (2006) Long-term effects of drainage and initial effects of hydrological restoration on rich fen vegetation. Appl Veg Sci 11:99-106

Matthews JW, Endress AG (2007) Performance criteria, compliance success, and vegetation development in compensatory mitigation wetlands. J Environ Manag 41:130-141

Matthews JW, Endress AG (2010) Rate of succession in restored wetlands and the role of site context. Appl Veg Sci 13:346-355

McCartney MP, Hera A (2004) Hydrological assessment for wetland conservation at Wicken Fen. Wetland Ecol Manage 12:189-204

Middleton B (1999) Wetland restoration flood pulsing and disturbance dynamics. Wiley, New York

Mitsch MJ (2007) Wetlands, 4th edn. Wiley, Hoboken

Mitsch WJ, Gosselink JG (1993) Wetlands, 2nd edn. Van Nostrand Reinhold, New York

Mitsch WJ, Wilson RF (1996) Improving the success of wetland creation and restoration with know-how, time, and self-design. Ecol Appl 6:77-84

Mitsch MJ, Wu X, Nairn RW, Weihe PE, Wang N, Deal R, Boucher C (1998) Creating and restoring wetlands. Bioscience 48:1019-1027

Moore PD, Bellamy DJ (1974) Peatlands. Elek Science, London

Mueller-Dombois D, Ellenberg H (1974) Aims and methods of vegetation ecology. Wiley, New York

Nakaike T (1992) New flora of Japan. In: Pteridophyta, revised and enlarged edn. Shibundo, Tokyo (in Japanese)

Nishimoto T (2001) Management and vegetation change of the Marsh Land Garden. Bull Okayama Pref Nature Cons Center 9:35-58 (in Japanese with English summary)

Nishimoto T (2008) Changes in vegetation communities in natural marshes of southern Okayama Prefecture over the last forty years-Fujiganaru marsh, Kugui marsh and Sayama marsh. Bull Okayama Pref Nature Cons Center 16:19-59 (in Japanese with English summary)

Nishimoto T, Hada Y (2002) Vegetation of the Marsh Land Garden in the Okayama Prefectural Nature Conservation Center 5. Vegetation in the 12th year after the transplantation. Bull Okayama Pref Nature Cons Center 10:35-48 (in Japanese with English summary)

Nishimura A, Tsuyuzaki S, Haraguchi A (2009) A chronosequence approach for detecting revegetation patterns after Sphagnumpeat mining, northern Japan. Ecol Res 24:237-246

Ohwi J (1983) New flora of Japan (revised by Kitagawa M). Shibundo, Tokyo

Pfadenhauer J, Grootjans A (1999) Wetland restoration in Central Europe: aims and methods. Appl Veg Sci 2:95-106

Pfadenhauer J, Klotzli F (1996) Restoration experiments in middle European terrestrial ecosystems: an overview. Vegetation 126:101-115

Satake Y, Ohwi J, Kitamura S, Watari S, Tominari T (1981) Wild flowers of Japan: herbaceous plants. Heibonsha, Tokyo

Schot PP, Barendregt A, Wassen MJ (2003) Hydrology of the wetland Naardermeer: influence of the surrounding area and impact on vegetation. Agric Water Manage 14:459-470

Suzuki H, Ito S, Toyohara G (1985) Vegetation method: phytosociological research method. Kyoritsu-Shuppan, Tokyo

Tsuji H (2001) Measures against vegetation rehabilitation and creation and issues for the future. Nature conservation and vegetation science in the 21 st century: ability and problems in the rehabilitation and creation of vegetation. Vege Inform (Society of Vegetation Science, Japan) 5:15-23 (in Japanese)

Tsuyuzaki S, Haraguchi A, Kanda F (2004) Effects of scaledependent factors on herbaceous vegetation patterns in a wetland, northern Japan. Ecol Res 19:349-355

Tzialla CE, Veresoglou DS, Papakosta D, Mamolos AP (2006) Changes in soil characteristics and plant floristic composition 
along a moisture gradient in a Mediterranean pasture. J Environ Manage 80:90-98

van der Valk (1981) Succession in wetlands; a Gleasonian approach. Ecology 62:688-696

van Diggelen R, Middleton B, Bakker J, Grootjans A, Wassen MJ (2006) Fens and floodplains of the temperate zone: present status, threats, conservation and restoration. Appl Veg Sci 9:157-162

van Loon AH, Schot PP, Bierkens MFP, Griffioen J, Wassen MJ (2009) Local and regional impact of anthropogenic drainage on fen contiguity. Hydrol Earth Syst Sci 13:1837-1848

Washu-kaihatsu Co. (1989) Environmental impact assessment report on construction of the Washu Golf Club, Okayama (in Japanese)
Wassen MJ, Grootjans AP (1996) Ecohydrogy: an interdisciplinary approach for wetland management and restoration. Vegetation 126:1-4

Waughman GJ (1980) Chemical aspects of the ecology of some south German peatlands. J Ecol 68:1025-1046

Yabe K, Nakamura T (2010) Assessment of flora, plant communities, and hydrochemical conditions for adaptive management of a small artificial wetland made in a park of a cool-temperate city. Landsc Ecol Eng 6:201-210

Yabe K, Sekizawa S, Kitahara Y (2002) Planting of mire grasses in an artificial wetland of Hiraoka Park, Sapporo City, northern Japan. Landscape 66:603-606 (in Japanese) 